\title{
Study of Biological Activities of Magnetic Iron Oxide Nanoparticles Prepared by Co-Precipitation Method
}

\author{
${ }^{1}$ Rania Hasan Hussein ${ }^{*},{ }^{2}$ Ali A. Taha, ${ }^{1}$ Oday Mahmood Abdulhusein \\ ${ }^{1}$ Applied Physics Division, Department of Applied Sciences, University of Technology, Baghdad - Iraq \\ ${ }^{2}$ Biotechnology Division, Department of Applied Sciences, University of Technology, Baghdad - Iraq
}

\section{Article information}

Article history:

Received: May, 06, 2021

Accepted: June, 14, 2021

Available online: June, 25, 2021

Keywords:

Ferrous Oxide nanoparticles,

Methylene blue removal,

Hemolysis activity

*Corresponding Author:

Rania Hasan Hussein

as.19.14@grad.uotechnology.edu.iq

\begin{abstract}
Iron oxides are the most common types of substances available in nature in various forms such as oxides, hydroxides and oxide-hydroxides, which obtained from various aqueous reactions. In the present study, iron oxide $\left(\mathrm{Fe}_{3} \mathrm{O}_{4}\right)$ nanoparticles (NPs) had been synthesized using co precipitation method and determined some biological activities. Iron oxide NPs had been characterized by spectrophotometry, X- Ray Diffraction (XRD) analysis and Field Emission Scanning Electron Microscopic (FE-SEM). The XRD analysis confirmed the purity and crystalline nature of fabricated NPs. In contrast, four biological activities of iron oxide NPs were determined. High removal of methylene blue pollutant dye (37.62 \%) was observed when iron oxide NPs were used at $400 \mu \mathrm{g} / \mathrm{ml}$ within $48 \mathrm{hrs}$. Furthermore, iron oxide NPs revealed high inhibition zones of 27.5 and $30 \mathrm{~mm}$, at $1000 \mu \mathrm{g} / \mathrm{ml}$, toward Staphylococcus aureus and Escherichia coli respectively. The hemolysis activity of fabricated NPs is increases whenever concentrations increased. The lower hemolysis percentage of iron oxide NPs was $(69.76 \%)$ when the NPs concentration was $250 \mu \mathrm{g} / \mathrm{ml}$. Finally, cytotoxic activity was estimated against MCF- 7 cell line and normal cell line WRL68 by MTT assay. Significant and decrease in viability of (MCF-7 to $65.1 \%$ ) when $400 \mu \mathrm{g} / \mathrm{ml}$ of iron oxide NPs was examined, while WRL68 viability was $(75.03 \%)$.
\end{abstract}

\section{Introduction}

Metal oxide nanoparticles have exceptional properties that lead to great interest in some biological activities. Iron $(\mathrm{Fe})$ is a transitional mineral and the backbone of the earth's crust appeared in different forms and magnetic properties, either as hematite $\left(\alpha-\mathrm{Fe}_{2} \mathrm{O}_{3}\right)$, magnetite $\left(\mathrm{Fe}_{3} \mathrm{O}_{4}\right)$ or maghemite $\left(\gamma-\mathrm{Fe}_{2} \mathrm{O}_{3}\right)[1,2]$. Magnetite is the most common types of substances available in nature in various forms such as oxides, hydroxides and oxide-hydroxides, are obtained from various aqueous reactions (oxidation and reduction) [3]. Iron oxide NPs revealed more stable, 
superparamagnetic, biocompatible, and low toxicity compounds. They also have high stability in water when exposed to difficult conditions such as high temperature and high $\mathrm{pH}$, and therefore their conjugation with biomolecules is very easy [4]. Moreover, synthesis methods of iron oxide NPs are extensively developed, like solgel, co-precipitation, thermal decomposition, and micro emulsion method [5]. On the other hand, iron oxide NPs have a high surface area to volume ratio, which gives the particles high binding ability and good dispersion in solution. Iron oxide nanoparticles have amazing magnetic properties and high biocompatibility that have attracted widespread interest in the biomedical field $[1,6]$. In the present study, iron oxide NPs synthesized using co precipitation process and then characterized by (UV-V) is spectroscopy, XRD and FE-SEM. The aim of this study is determining their compatibility, the ability to remove pollutant dye, hemolysis, antibacterial and antitumor activities had been investigated.

\section{Experimental Work}

\subsection{Chemicals and Cells}

Iron (II) chloride tetrahydrate $\left(\mathrm{FeCl}_{2} \cdot 4 \mathrm{H}_{2} \mathrm{O}_{2}\right)$, Iron (III) chloride $\left(\mathrm{FeCl}_{3}\right)$, and Ammonium hydroxide $\left(\mathrm{NH}_{4} \mathrm{OH}\right)$ were bought from Merck (India). Each solution was prepared to utilize deionized water. Bacterial isolates of Staph, aureus and E. coli were purchased from medical lab technique, Al Esraa university, Baghdad, Iraq, while MCF-7 and WRL68 cell lines were supplied by Sterllixir Biotech, industrial area, Bangalore, India.

\subsection{Synthesis of Magnetic Iron Oxide NPs}

The co-precipitation method was used for $\mathrm{Fe}^{3+}$ ions and $\mathrm{Fe}^{2+}$ ions to synthesize magnetic $\mathrm{Fe}_{3} \mathrm{O}_{4}$ nanoparticles in the presence of ammonium hydroxide solution $\left(\mathrm{NH}_{4} \mathrm{OH}\right)$. The synthesis process was accomplished by mixing $4.58 \mathrm{~g}$ of $\mathrm{FeCl}_{2} .4 \mathrm{H}_{2} \mathrm{O}$ with $8.93 \mathrm{~g} \mathrm{FeCl}_{3} .6 \mathrm{H}_{2} \mathrm{O}$ and dissolving them in an aqueous medium $(80 \mathrm{~mL})$. The solution was then heated at $80{ }^{\circ} \mathrm{C}$ with continues stirring. After heating, $10 \mathrm{~mL}$ of $\mathrm{NH}_{4} \mathrm{OH}$ solution is added to the reaction solution. Crystal growth continuous for 30 minutes without changing the reaction conditions. Then the reaction solution is purified by washing it several times with distilled water drying in an oven at $50{ }^{\circ} \mathrm{C}$ [7].

\subsection{Characterization of Iron Oxide NPs}

(UV-Vis) is absorption spectra of iron oxide NPs were determined on UV-1800 spectrophotometer (Shimadzu, Kyoto, Japan). The crystal phase and particles size of the prepared sample was identified by X-ray technology (XRD-6000, Shimadzu) with $\mathrm{Cu} \mathrm{K \alpha}$ source (wavelength of $1.54056^{\circ} \mathrm{A}$ ) at diffraction angle (20) from $20^{\circ}$ to $80^{\circ}$. Furthermore, the morphology of the prepared iron oxide NPs can be identified by field emission scanning electron microscopy (Mira 3-TESCAN) and quickening voltage (20-30 kV).

\subsection{Biological Activities Determination of $\mathrm{Fe}_{3} \mathrm{O}_{4} \mathrm{NPs}$ 2.4.1. Removal of Methylene Blue}

The adsorption activity of methylene blue dye has been studied. Various concentrations $(5-20 \mathrm{mg})$ of the prepared iron oxide NPs with methylene blue dye $\left(50 \mathrm{~mL}, 40 \mathrm{mg} \mathrm{L}^{-1}\right)$ had been mixed. The reaction solution was mixed over a hot plate stirrer at different times $2-72 \mathrm{hr}$. and the process was repeated three times at room temperature. Finally, the removal percentage of methylene blue dye was measured using UV-Vis spectroscopy at wavelength $668 \mathrm{~nm}$. Kinetics of adsorption was studied by analyzing adsorptive uptake of the dye color from the aqueous solution at different time intervals [8].

\subsubsection{Antibacterial Activity}

The well-diffusion technique was utilized in [9] with some modification. Fifty microliter of E. coli, and S. aureus cultures of 18-24 h (10 / CFU/ ml) growth were spread on the surface of sterilized Mueller-Hinton agar (Oxoid, England) poured in Petri plates. Wells were made and each well was packed with different concentrations of iron oxide NPs ranging from $250,500,750$, and $1000 \mu \mathrm{g} / \mathrm{ml}$ DMSO. The plates were incubated at $37{ }^{\circ} \mathrm{C}$ for 24 . DMSO was used as control. The antibacterial activity of (DMSO) used as control. The average of inhibition zones of duplicate treatment was determined in millimeters [9].

\subsubsection{Hemolytic Activity Assay}

Hemolytic activity of $\mathrm{Fe}_{3} \mathrm{O}_{4}$ NPs was established according to the procedure mentioned in [10] with some modification. Briefly, $200 \mu \mathrm{L}$ of the separated blood was mixed with $1600 \mu \mathrm{L}$ of normal saline. Then, $200 \mu \mathrm{L}$ of 
different concentrations of NPs $(250,500,750$, and $1000 \mu \mathrm{g} / \mathrm{mL})$ were added to the diluted blood. The samples were incubated at $37^{\circ} \mathrm{C}$ for $1 \mathrm{~h}$ and centrifuged at $700 \mathrm{rpm}$ for $5 \mathrm{~min}$. Positive and negative control includes Distilled water and normal saline, respectively, were used for comparison. Sample absorbance was measured spectrophotometry at $541 \mathrm{~nm}$ and hemolysis percentage was estimated by utilizing the following equation 1 [10]:

Hemolysis $(\%)=\mathbf{A}$ test sample $-\mathbf{A}(-) \operatorname{control} \backslash \mathbf{A}(+) \operatorname{control}-\mathbf{A}(-)$ control $x 100$

Where, A: is the absorbance. The absorbance of positive and negative controls was found to be 1.764 and 0.048 , respectively and A (-): is Negative control includes distilled water and A (+): is Positive control includes distilled water with normal saline.

\subsubsection{Anticancer Activity}

MCF-7 and WRL 68 cell lines were grown in RPMI-1640 medium (Sigma-Aldrich, USA) at $37{ }^{\circ} \mathrm{C}$ with $5 \% \mathrm{CO}_{2}$ in 96 - well flat bottom culture plates at density $1 \times 10^{4}$ cells $/ \mathrm{ml}$ for $48 \mathrm{hrs}$. The cells were treated, in duplicate, with the concentrations of $20-400 \mu \mathrm{g} / \mathrm{ml}$ of NPs and incubated for $24 \mathrm{hrs}$. to determine the toxicity against examined cell lines. $10 \mu \mathrm{l}$ of MTT solution was added to each well, and the plates were incubated for 4 hrs. at 37 ${ }^{\circ} \mathrm{C}$. The media were then removed, and the remaining formazan crystals were dissolved in DMSO, and the absorbance was measured at $570 \mathrm{~nm}$ using an ELISA microplate reader to determine the toxicity, once with a tumor cell line and another with normal cells. The cytotoxicity percentage was calculated by the equation 2 [11]:

$$
\text { Growth Inhibition rate } \%(G . I)=\frac{A-B}{A} \times 100
$$

A: an optical density of the control, B: an optical density of the treated sample.

\section{Results and Discussion}

\subsection{Characterization of Iron Oxide NPs}

\subsubsection{UV-Vis Spectrophotometry Analysis}

UV-Vis Spectroscopy is an analytical technique used to identify the absorbance of colloidal solutions and the optical properties of prepared compounds in a range of wavelengths (200-800) nm. Figure 1a, b shows the absorption spectrum of $\mathrm{Fe}_{3} \mathrm{O}_{4}$ NPs. The spectrum of $\mathrm{Fe}_{3} \mathrm{O}_{4} \mathrm{NPs}$ shows continuous absorption along wavelengths and no strong absorption peaks observed. The results are similar to previous literature by Nagaraj et al.,[12] and Yen et al., [13]. Moreover, the band gap energy spectrum of $\mathrm{Fe}_{3} \mathrm{O}_{4} \mathrm{NPs}$ had been determined, as exhibited in Figure (1 b). The optical band gap energy can be calculated from the Tauc's equation 3 [14]:

$$
(\alpha h v)^{2}=C\left(h v-E_{g}\right)^{2}
$$

Where, $\mathrm{E}_{\mathrm{g}}$ is the band gap of the sample, $\mathrm{h}$ is blank constant, $\mathrm{C}$ is a constant, and $\alpha$ is the absorption coefficient. The gap energy is estimated by drawing $(\alpha h v)^{2}$ against the photon energy (hv). It was found that the gap energy value of the $\mathrm{Fe}_{3} \mathrm{O}_{4} \mathrm{NPs}$ up to $5.22 \mathrm{eV}$. 

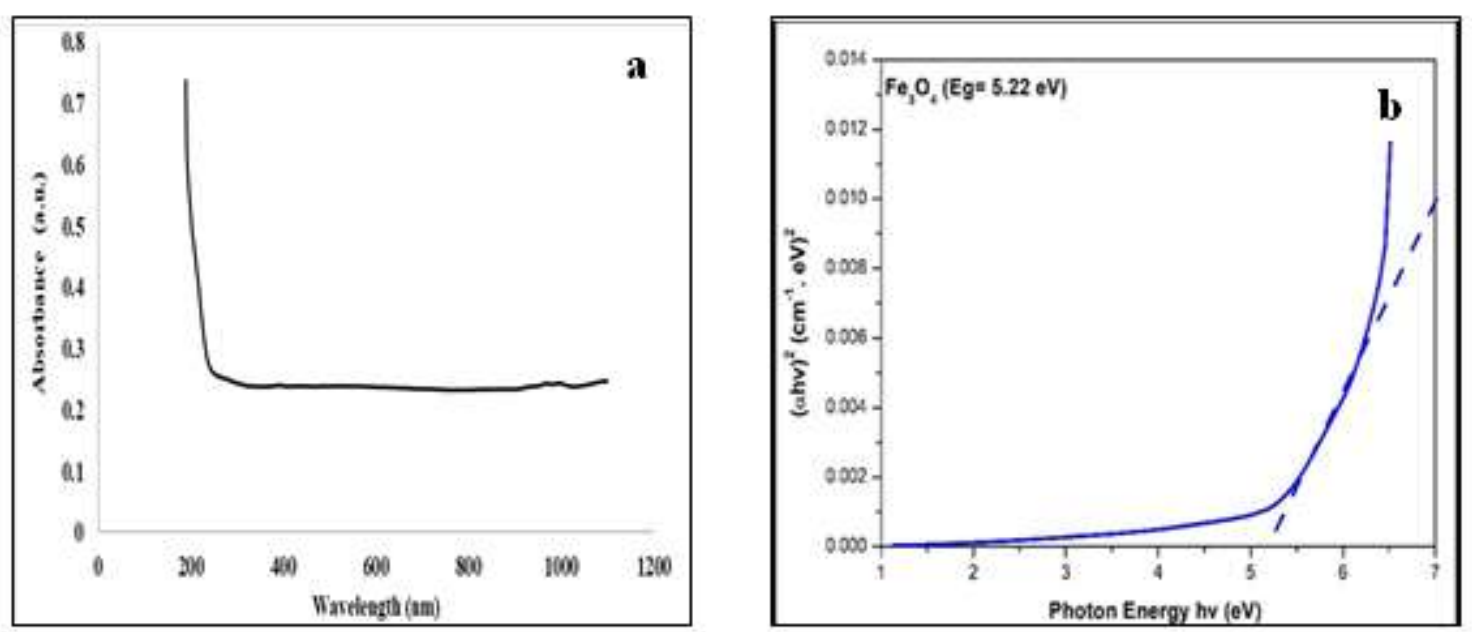

Figure 1: (a) UV-Vis Spectra properties of preparation $\mathrm{Fe}_{3} \mathrm{O}_{4} \mathrm{NPs}$ and (b) the value of $E_{\mathrm{g}}$ using plot of $(\alpha h v)^{2}$ versus energy.

\subsubsection{X-Ray Diffraction Analysis}

$\mathrm{XRD}$ is an analytical technique utilized to identify the crystalline nature and particle size of prepared crystalline nanomaterials. Figure 2 represents the XRD patterns of $\mathrm{Fe}_{3} \mathrm{O}_{4} \mathrm{NPs}$. XRD patterns of $\mathrm{Fe}_{3} \mathrm{O}_{4} \mathrm{NPs}$ exhibited the diffraction peaks of $2 \theta=30.77^{\circ}, 36.42^{\circ}, 43.48^{\circ}, 54.53^{\circ}, 56.78^{\circ}$, and $62.28^{\circ}$ corresponding to the hkl planes of $(220)$, (311), (400), (422), (511) and (440), respectively as explained in Table 1. This point to the cubic spinel structure of $\mathrm{Fe}_{3} \mathrm{O}_{4}$ (JCPDS Card No: 19-629). The nonappearance of additional peaks in the spectrum indicates the high purity of the $\mathrm{Fe}_{3} \mathrm{O}_{4}$ NPs [15]. The average crystal size of $\mathrm{Fe}_{3} \mathrm{O}_{4}$ is $31.27 \mathrm{~nm}$ calculated from Debye Scherer's equation 4 [16]:

$$
D=\frac{k \lambda}{\beta \cos \theta}
$$

Whereas $\mathrm{D}$ represents crystal size, $\theta$ is diffraction angle (deg.), $\lambda$ is the $\mathrm{X}$-ray wavelength $(0.15056 \mathrm{~nm}), \mathrm{k}$ is a dimensionless shape factor $(0.9)$, FWHM $(\beta)$ is the full width at half maximum of the peak. The results are similar to previous literature $[17,18]$.

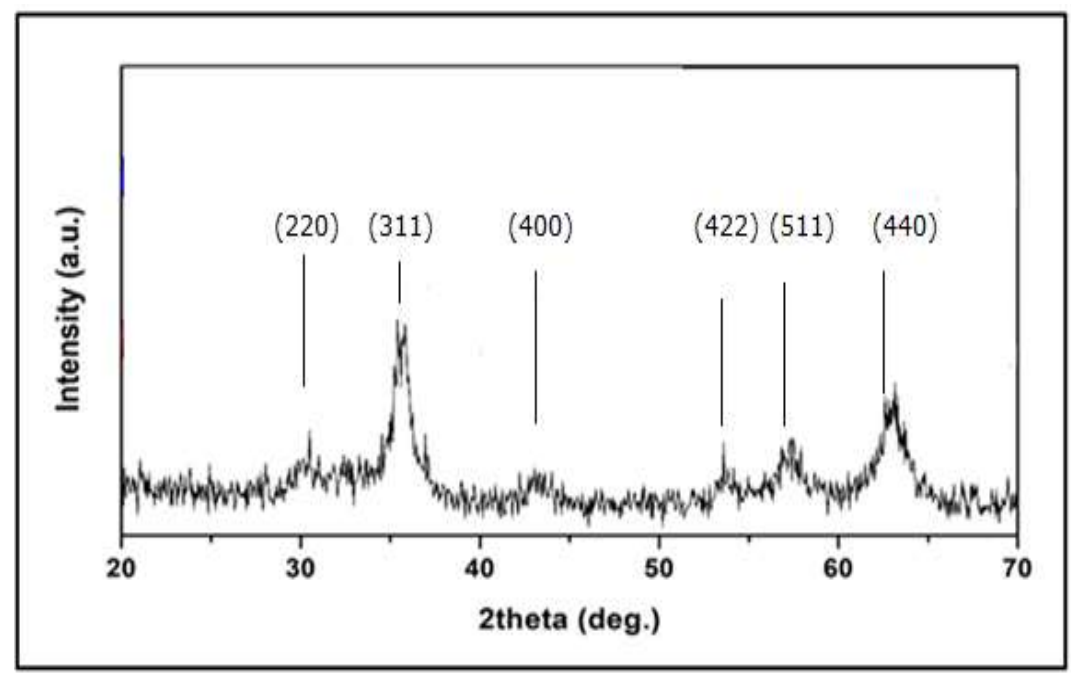

Figure 2: X- Ray diffraction spectra of $\mathrm{Fe}_{3} \mathrm{O}_{4}$ NPs. 
Table 1: XRD analysis for $\mathrm{Fe}_{3} \mathrm{O}_{4} \mathrm{NPs}$.

\begin{tabular}{ccccc}
\hline $2 \theta$ & Plane & FWHM & Crystalline Size D $(\mathrm{nm})$ & $\mathrm{d}\left(\mathrm{A}^{\mathrm{o}}\right)$ \\
30.77 & $(220)$ & 0.1858 & 31.27 & 2.3622 \\
36.42 & $(311)$ & 0.2841 & & 2.3452 \\
43.48 & $(400)$ & 0.3735 & & 2.0844 \\
54.53 & $(422)$ & 0.2944 & & 1.6763 \\
56.78 & $(511)$ & 0.6880 & & 1.6207 \\
62.28 & $(440)$ & 0.4420 & & 1.4771 \\
\hline
\end{tabular}

\subsubsection{FE-SEM Images}

FE-SEM is an analysis that provides information about surface morphology and particle size of the prepared samples. Figure 3 displays the FE-SEM analysis of iron oxide NPs. The microscopic images reveal the presence of spherical particles of different sizes and distribution. Also, an increase in the ratio of particle agglomeration was noticed due to the electrostatic interaction between the layers of nanoparticles.
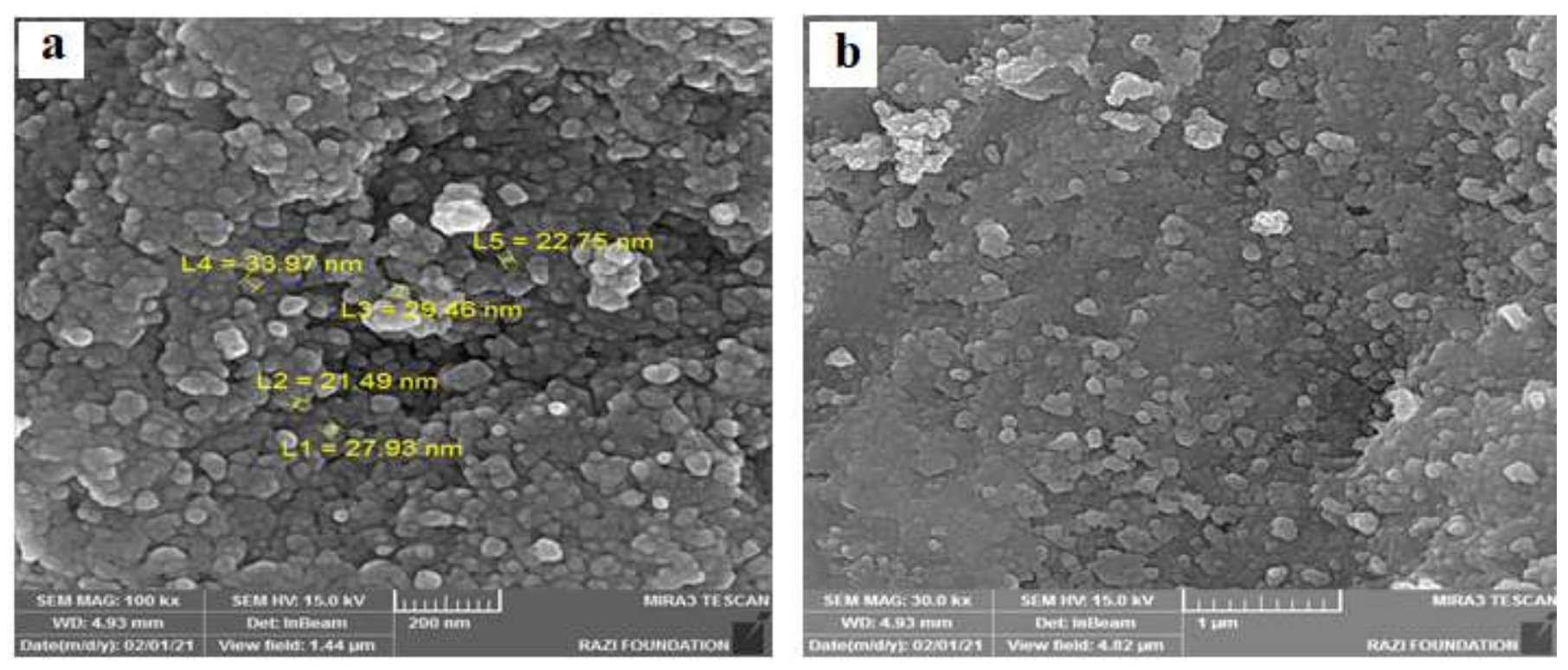

Figure 3: FE-SEM images of $\mathrm{Fe}_{3} \mathrm{O}_{4}$ NPs with different magnifications (a) at scale bar $=200 \mathrm{~nm}$ and (b) scale bar $=1 \mu \mathrm{m}$.

The average particle size is $27.12 \mathrm{~nm}$, close to the crystal size calculated from the XRD diffraction analysis. The results show the formation of iron oxide nanoparticles, and this is in agreement with was previously published research [19]. On the other hand, EDS a diagnostic tool used to identify the elementary components of the chemical composition of the prepared sample. Figure 4 represents to EDS spectrum of iron oxide NPs with strong peak for the oxygen element and weak peaks for the Fe element were observed, indicating the formation of $\mathrm{Fe}_{3} \mathrm{O}_{4}$ compound. The results are identical to previous studies prepared by Saddam et al,.[9]. 


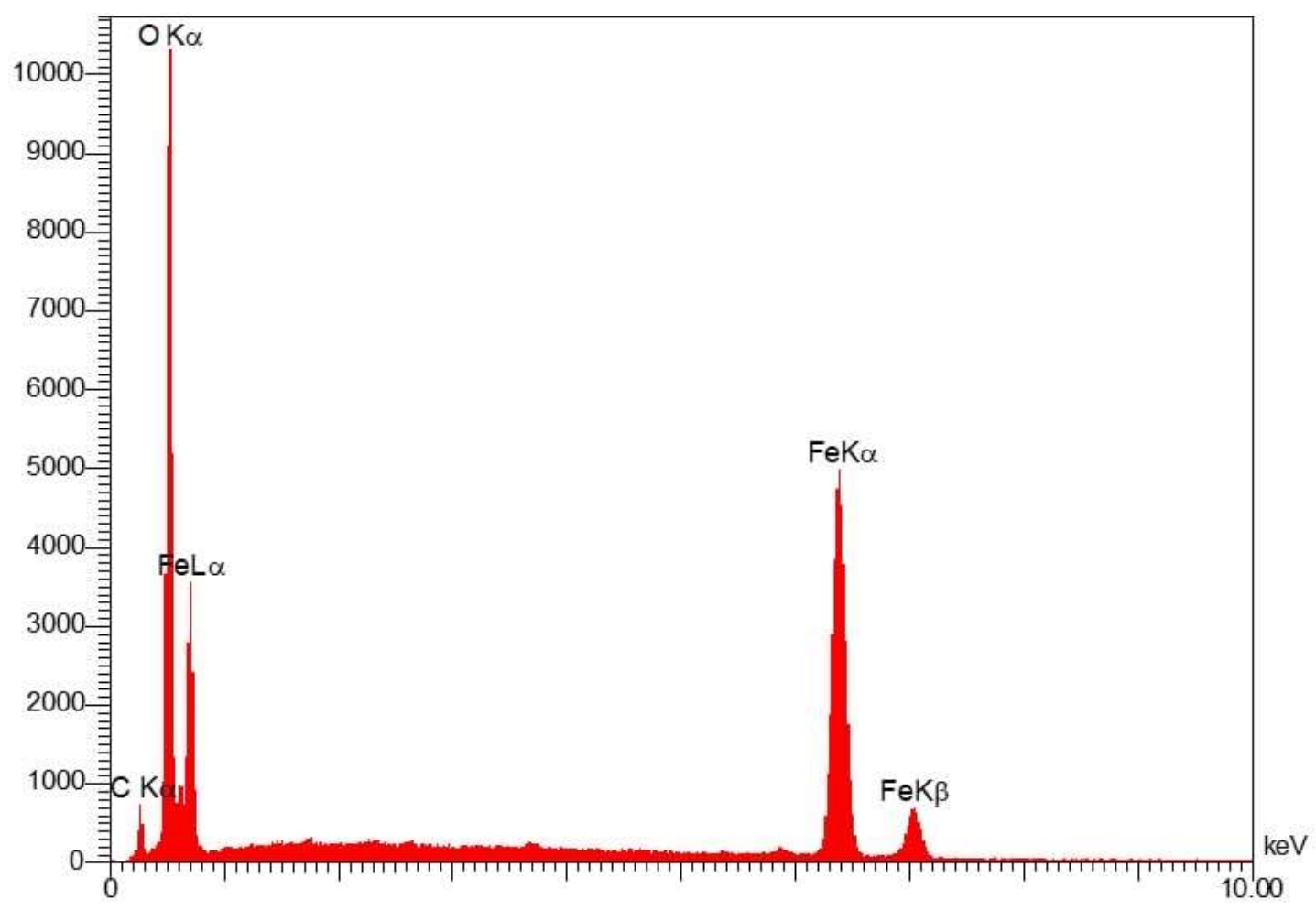

Figure 4: Energy dispersive spectroscopy of $\mathrm{Fe}_{3} \mathrm{O}_{4} \mathrm{NPs}$.

\subsection{Biological Activities of iron oxide NPs}

\subsubsection{Removal of Methylene Blue (MB) Dye}

Methylene blue had been used as pollutant dye model. The removal percentage of the dye had been estimated in the existence of iron oxide NPs in liquid phase. Absorbance of removed dye was measured in the existence of various concentrations of iron oxide NPs by spectrophotometer at $668 \mathrm{~nm}$, within $48 \mathrm{hrs}$. at room temperature. High and significant removal of dye (37.62 \%) was observed when iron oxide NPs was used at $400 \mu \mathrm{g} / \mathrm{ml}$ within $48 \mathrm{hr}$ as shown in Figure 5. Most destruction and disruption of water ecosystems caused by untreated dye came from different industrial products, like textile, paper, and food processes. Further than their toxicity, most dyes are mutagenic and carcinogenic agents. Synthetic methylene blue is a cationic and aromatic dye used wildly in textile industry that cause skin damage and eyes allergy and other defects when ingested [20, 21]. Different remedying methods have been applied to remove methylene blue from water environments. The rapid and specific technique is the method of choice to isolate and concentrate the specific pollutant from water system. Magnetic nanoparticles represent easily and cheap prepared adsorbent material to remove contaminations [22]. On the other hand, although the reported advantages of nanoparticles, the toxicity of the iron oxide NPs need more to explore. Despite whether the applications were in vivo or in vitro, iron oxide NPs should be biocompatible and non-toxic. Moreover, surface area to volume of nanoparticles, size, shape, concentration of NPs, concentration of methylene blue, reaction temperature, type of coat, and $\mathrm{pH}$ effect dye removal [23]. Therefore, the results obtained in the study appeared low removal of methylene blue in contrast to results obtained by other studies [24]. 


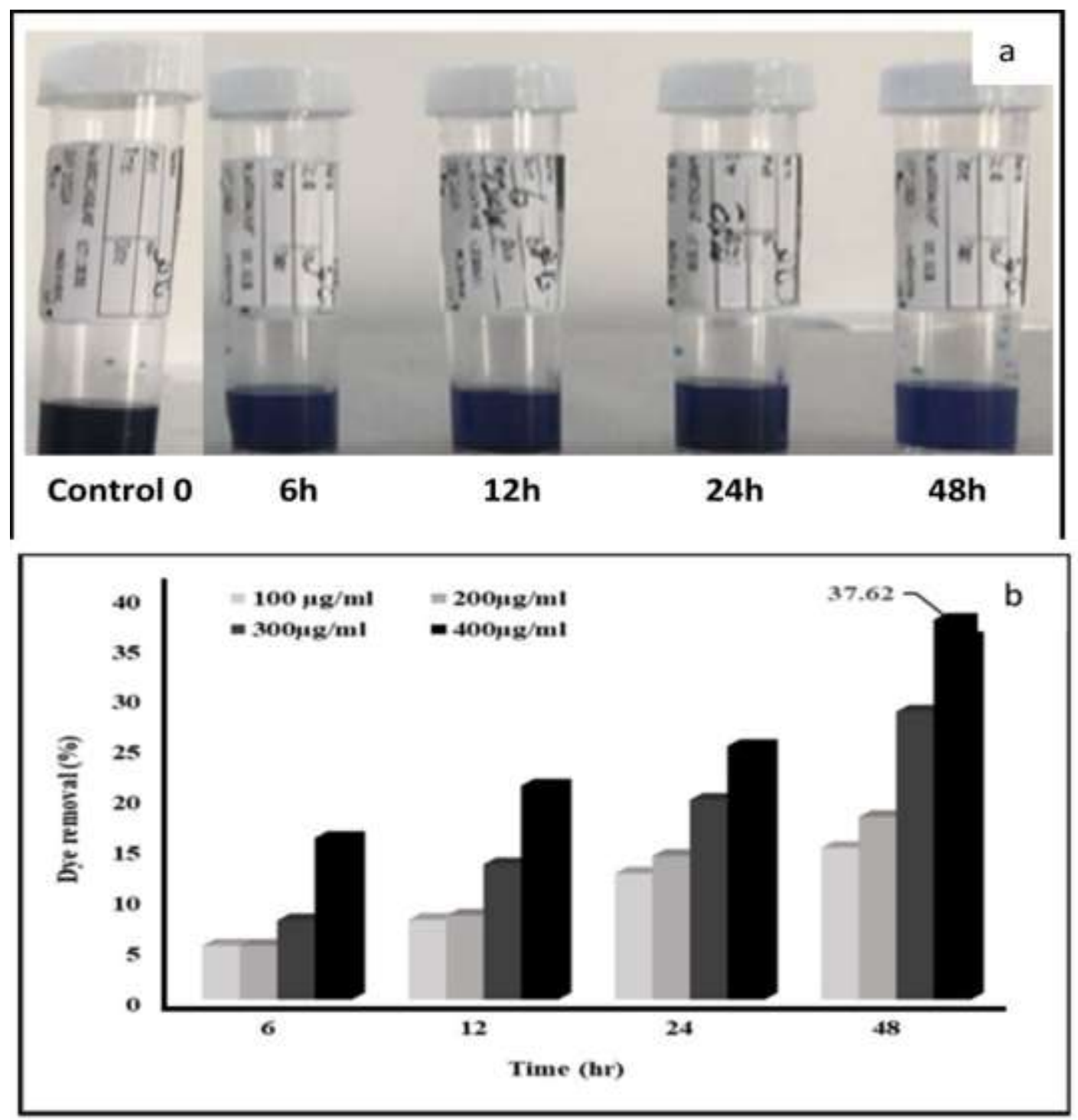

Figure 5: Methylene blue removal, (a) dye color changed using concentration $400 \mu \mathrm{g} / \mathrm{ml}$ of $\mathrm{Fe}_{3} \mathrm{O}_{4} \mathrm{NPs}$ (b) Dye removal percent using different concentrations of $\mathrm{Fe}_{3} \mathrm{O}_{4} \mathrm{NPs}$, within $48 \mathrm{hr}$.

\subsubsection{Antibacterial activity}

Various concentrations of $\mathrm{Fe}_{3} \mathrm{O}_{4} \mathrm{NPs}$ had been examined against E. coli (Gram negative) and S. aureus (positive bacteria. The well diffusion method was used to detected the antibacterial activity of $\mathrm{Fe}_{3} \mathrm{O}_{4} \mathrm{NPs}$ on Muller Hinton medium within $24 \mathrm{hrs}$. at $37^{\circ} \mathrm{C}$. Results were expressed as mean \pm standard error (SE) and values of $\mathrm{p}<0.05$ were considered significant. The obtained results demonstrated that iron oxide NPs have antibacterial activity against both $E$. coli and $S$. aureus and the activity increases with an increase in concentration of nanoparticles. The oxide NPs, at $1000 \mu \mathrm{g} / \mathrm{ml}$, revealed Highest and significant inhibition zones of 27.5 and $30 \mathrm{~mm}$ in diameter against $S$. aureus and E. coli, as shown in Figure 6. the other hand, investigation in many research had been done to explain the mechanism of iron oxide NPs antibacterial activity. One of the mechanisms referred to the interaction between opposite charge between the negative charge of bacterial surface and the potential positive charge of nanoparticles [25]. Due to the presence of positive charge on the surface of prepared iron oxide NPs [10,5], we think the attracted electrostatic led to an increase in the interaction between prepared NPs and the examined bacteria. Furthermore, in the present study iron oxide NPs could be the source that produces reactive oxygen species (ROS) leading to the inhibition of bacterial growth. 

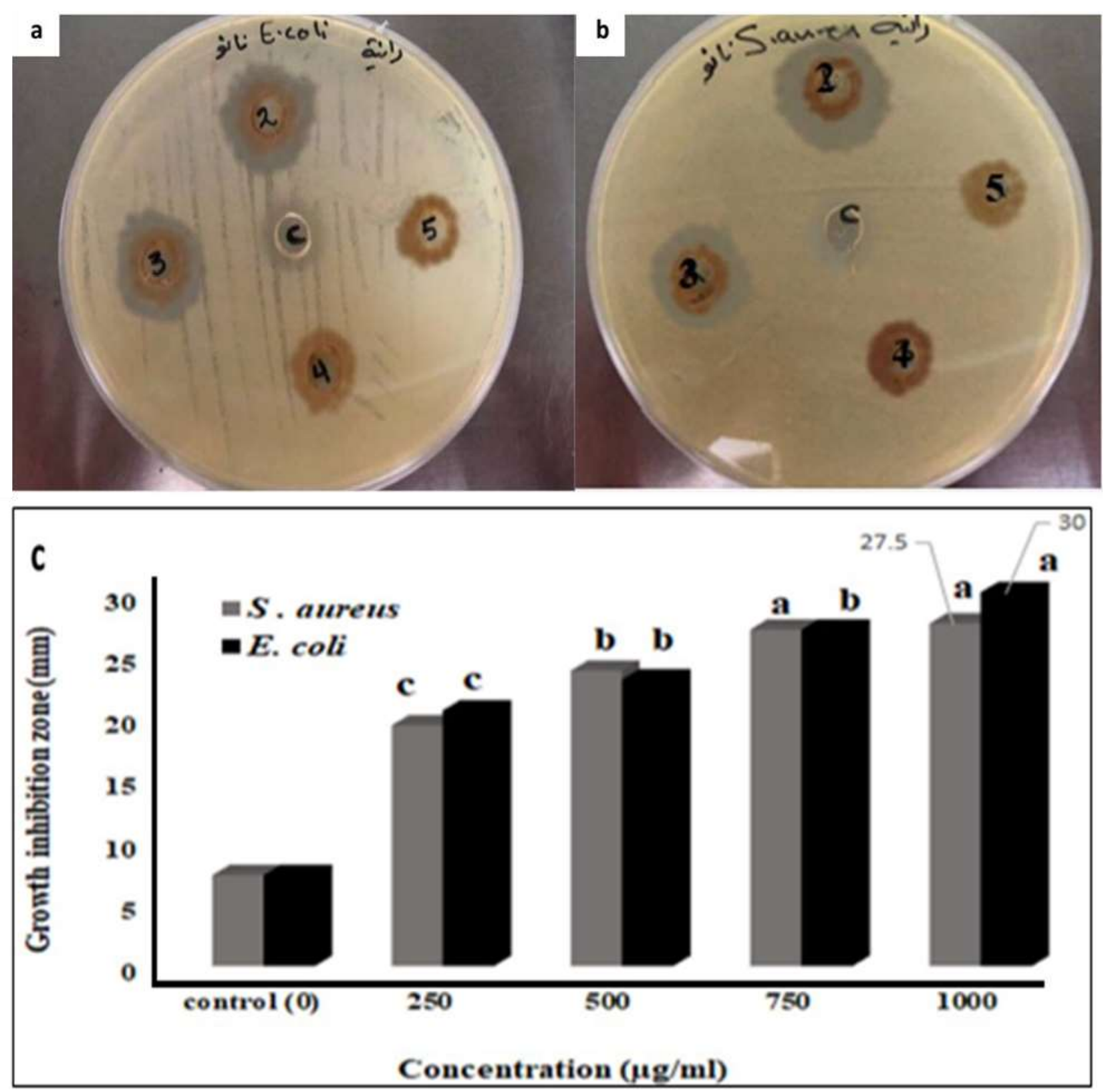

Figure 6: Inhibition Zone diameter around well filled with different concentrations of antibacterial $\mathrm{Fe}_{3} \mathrm{O}_{4}$ NPs (a) E. coli (b) S. aureus and (c) the Bar diagram of antibacterial $\mathrm{Fe}_{3} \mathrm{O}_{4} \mathrm{NPs}$.

\subsubsection{Hemolysis Activity}

The absorbance of human red blood cells corpuscles (RBC) lysis had been determined by spectrophotometer at $541 \mathrm{~nm}$ within one hour at $37{ }^{\circ} \mathrm{C}$. According to the standard ISO 10993-4 to evaluate materials and devices that compatible for blood cells, the hemolysis percentage should be less than 5 [27]. Different concentrations of iron oxide NPs were used to estimate their hemolysis activity, as shown in Figure 7. The hemolysis activity of iron oxide NPs is increasing whenever concentrations increased. Lower hemolysis percentages of iron oxide NPs $(69.76 \%)$ were observed at concentration of $250 \mu \mathrm{g} / \mathrm{ml}$. Iron oxide NPs have wildly investigated and developed for biological and medical applications, but a few studies discussed the biocompatibility and less on their hemocompatibility. The concentration of iron oxide NPs and incubation time are other factors that affect hemolysis 
estimation in vitro. Hemolysis rates were found to be lower than $2 \%$ for a low content $17.4 \mu \mathrm{g} / \mathrm{ml}$ and the highest $34.8 \mu \mathrm{g} / \mathrm{ml}$ of iron oxide NPs [28], while another study revealed maximum hemolysis $(5.11 \%)$ was obtained at $125 \mu \mathrm{g} / \mathrm{ml}$ of iron oxide NPs [29]. On contrast study, the results indicate that the iron oxide NPs had non-hemolytic reaction at all examined concentrations up to $3.0 \mathrm{mg} / \mathrm{ml}[30]$.
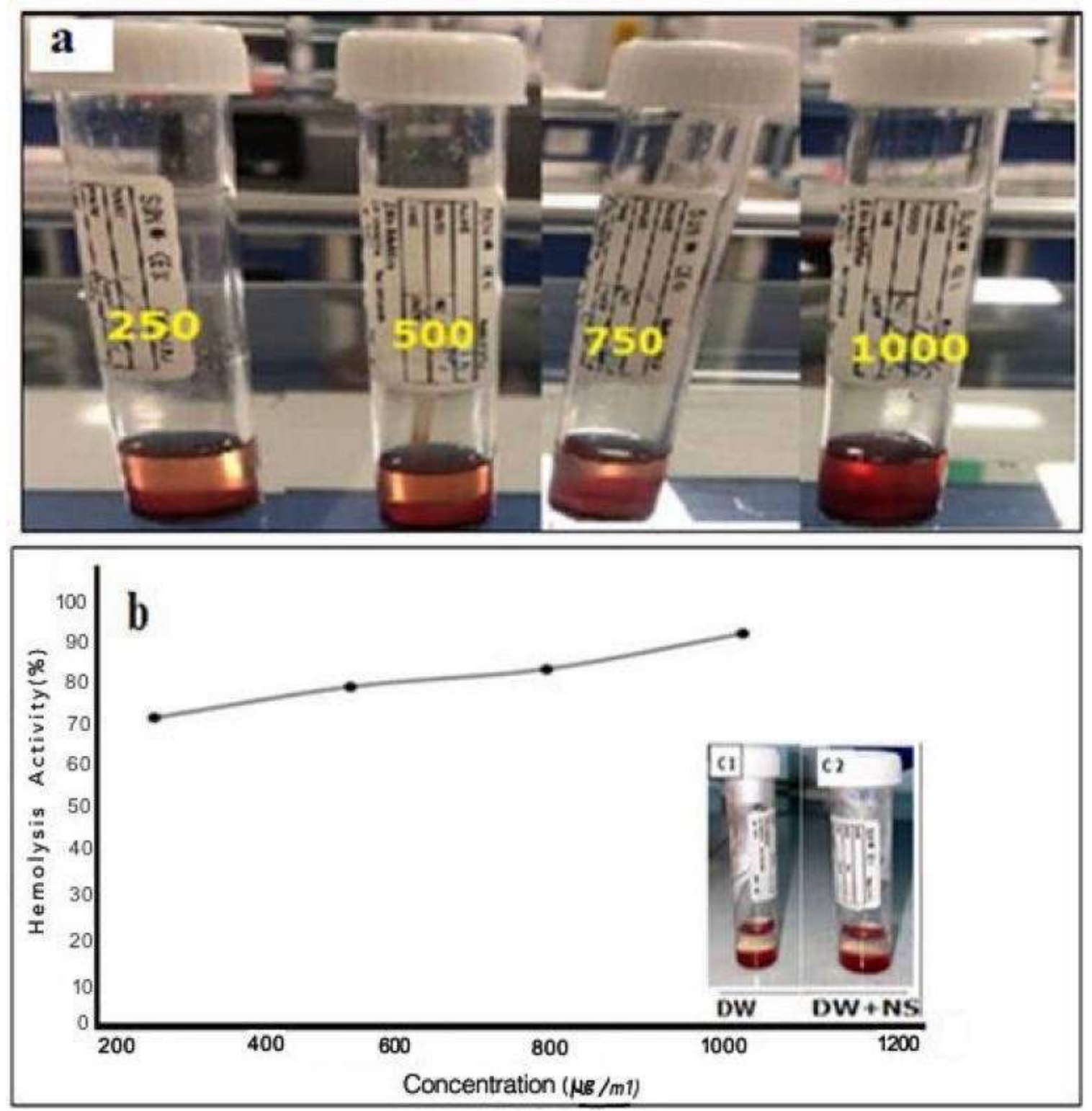

Figure 7: Hemolytic activity of $\mathrm{Fe}_{3} \mathrm{O}_{4}$ NPs (a) RBC lysis, (b) hemolysis percent by different concentrations (250$1000 \mu \mathrm{g} / \mathrm{ml}$ ) of $\mathrm{Fe}_{3} \mathrm{O}_{4}$ NPs and (c) is 1: distilled water and 2: distilled water with normal saline.

\subsubsection{Antitumor activity}

Antitumor activity of different concentrations of iron oxide NPs were measured against MCF-7, as tumor cell line, and WRL68, as normal cell line. The MTT assay was used to determine cell viability after incubation of 25, 50 ,100, 200 and $400 \mu \mathrm{g} / \mathrm{ml}$ of NPs at $37{ }^{\circ} \mathrm{C}$ for $24 \mathrm{hr}$. in the presence of $5 \% \mathrm{CO}_{2}$. Significant and decreasing MCF7 viability reach $65.1 \%$ when $400 \mu \mathrm{g} / \mathrm{ml}$ of iron oxide NPs were examined, while the viability of WRL68 was $75.03 \%$, as shown in Figure 8. Tumor can be treated either physically by radiation and hyperthermia or chemically by intracellular entry of nanoparticles to induce ROS and most importantly, the apoptotic, programmed cell death, and necrotic, direct cell damage, in tumor cells populations. The apoptotic and necrotic populations in MCF-7 cells increased by $61 \%$ in $200 \mu \mathrm{g} / \mathrm{mL}$ of iron oxide NPs [31]. Moreover, treatment of DU145 and PC-3 cell lines 
with $100 \mu \mathrm{g} / \mathrm{mL}$ iron oxide NPs for $72 \mathrm{~h}$ resulted in significant inhibition of cell viability [32]. On the other hand, iron oxide NPs with $39 \mathrm{~nm}$ in size appeared a remarkable antitumor activity against renal tumor at concentration of $400 \mu \mathrm{g} / \mathrm{ml}[33-35]$.

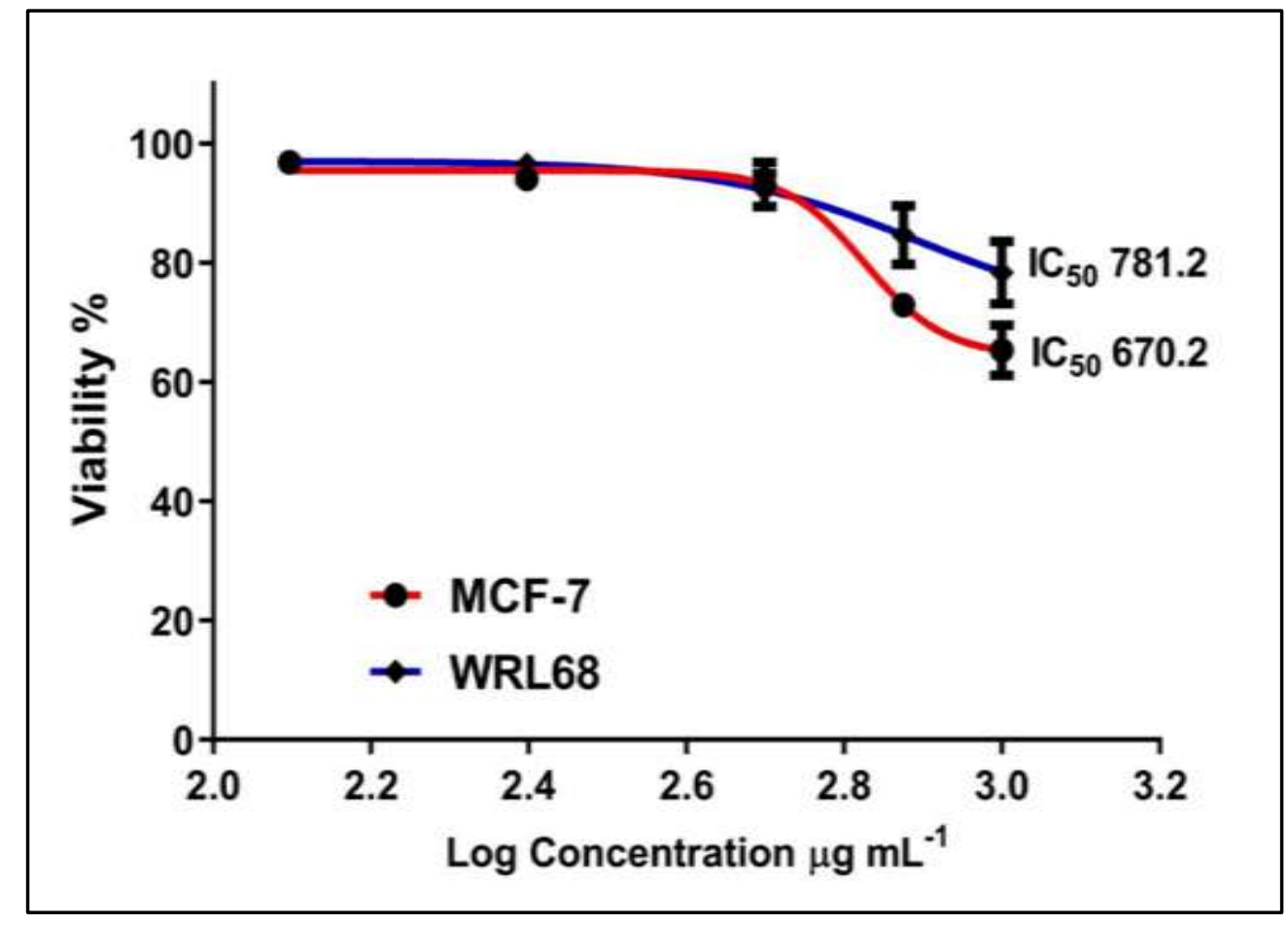

Figure 8: Antitumor activity of different concentrations $\mathrm{Fe}_{3} \mathrm{O}_{4} \mathrm{NPs}$ determined by MTT assay against MCF and WRL68 cell lines.

\section{Conclusions}

The synthesis of iron oxide NPs by co - precipitation method revealed purity and crystalline nature by XRD. The FE-SEM images of iron oxide NPs reveal a homogeneous structure with spherical shapes closely related to each other. Iron oxide NPs can remove methylene, as a pollutant dye, but it needs more optimization. Moreover, the hemolysis activity of fabricated NPs is increasing whenever concentrations increased. On the other hand, it seems to be $E$. coli was more sensitive to iron oxide NPs than $S$. aureus. Finally, the iron oxide NPs revealed low toxicity against both MCF-7 and WRL 68, as tumor and natural cell lines, respectively.

\section{Conflict of Interest}

The authors declare that they have no conflict of interest.

\section{References}

[1] A. Ali, M.Z. Hira Zafar, I. ul Haq, A.R. Phull, J.S. Ali, A. Hussain, Synthesis, characterization, applications, and challenges of iron oxide nanoparticles, Nanotechnology, science and applications, vol. 9, p. 49, 2016.

[2] L. Machala, J. Tucek, R. Zboril, Polymorphous transformations of nanometric iron (III) oxide: a review, Chemistry of Materials, vol. 23, pp. 3255-3272, 2011.

[3] A.S. Teja, P.-Y. Koh, Synthesis, properties, and applications of magnetic iron oxide nanoparticles, Progress in crystal growth and characterization of materials, vol. 55, pp. 22-45,2009.

[4] A.V. Samrot, C.S. Sahithya, J. Selvarani, S. Pachiyappan, Surface-engineered super-paramagnetic iron oxide 
nanoparticles for chromium removal, International journal of nanomedicine, vol.14, p. 8105, 2019.

[5] M.O. Ansari, M. Ahmad, N. Parveen, S. Ahmad, S. Jameel, G. Shadab, Iron oxide nanoparticles-synthesis, surface modification, applications and toxicity: a review, Materials Focus, vol.6, pp 269-279,2017.

[6] O.A. Noqta, A.A. Aziz, I.A. Usman, M. Bououdina, Recent advances in iron oxide nanoparticles (IONPs): synthesis and surface modification for biomedical applications, Journal of Superconductivity and Novel Magnetism, vol.32, pp. 779-795,2019.

[7] S.A.M.K. Ansari, E. Ficiarà, F.A. Ruffinatti, I. Stura, M. Argenziano, O. Abollino, R. Cavalli, C. Guiot, F. D'Agata, Magnetic iron oxide nanoparticles: synthesis, characterization and functionalization for biomedical applications in the central nervous system, Materials, vol.12, p. 465,2019.

[8] A. Alinejad-Mir, A.A. Amooey, S. Ghasemi, Adsorption of direct yellow 12 from aqueous solutions by an iron oxide-gelatin nanoadsorbent; kinetic, isotherm and mechanism analysis, Journal of Cleaner Production, vol. 170, pp. 570-580,2018.

[9] S. Saqib, M.F.H. Munis, W. Zaman, F. Ullah, S.N. Shah, A. Ayaz, M. Farooq, S. Bahadur, Synthesis, characterization and use of iron oxide nano particles for antibacterial activity, Microscopy research and technique, vol.82, pp. 415-420,2019.

[10] Singh DK Graft AK. Graft copolymerization of 2- hydroxymethacrylate onto chitosan film and their blood compatibility. J. Appl. Polym. Sci.vol. 53, pp.1115-1121,1994.

[11] R.I. Freshney, Culture of animal cells: a manual of basic technique and specialized applications, John Wiley \& Sons, 2015.

[12] N. Basavegowda, K.B.S. Magar, K. Mishra, Y.R. Lee, Green fabrication of ferromagnetic $\mathrm{Fe}_{3} \mathrm{O}_{4}$ nanoparticles and their novel catalytic applications for the synthesis of biologically interesting benzoxazinone and benzthioxazinone derivatives, New Journal of Chemistry, vol. 38, pp. 5415-5420,2014.

[13] Y.P. Yew, K. Shameli, M. Miyake, N. Kuwano, N.B.B.A. Khairudin, S.E.B. Mohamad, K.X. Lee, Green synthesis of magnetite $\left(\mathrm{Fe}_{3} \mathrm{O}_{4}\right)$ nanoparticles using seaweed (Kappaphycus alvarezii) extract, Nanoscale research letters, vol.11, pp. 1-7,2016.

[14] K. Tharani, L. Nehru, Synthesis and characterization of iron oxide nanoparticle by precipitation method, Int $J$ Adv Res Phys Sci,vol. 2,pp. 47-50,2015.

[15] S. Bao, K. Li, P. Ning, J. Peng, X. Jin, L. Tang, Highly effective removal of mercury and lead ions from wastewater by mercaptoamine-functionalised silica-coated magnetic nano-adsorbents: behaviours and mechanisms, Applied Surface Science, vol.393, pp. 457-466,2017.

[16] N. Budiredla, A. Kumar, S. Thota, J. Kumar, Synthesis and optical characterization of $\mathrm{Mg}_{1-\mathrm{x}} \mathrm{Ni}_{\mathrm{x}} \mathrm{O}$ nanostructures, International Scholarly Research Notices, vol. 2012 p. 8, 2012.

[17] B. Gaihre, Y. Hee Lee, M. Seob Khil, H. Keun Yi, H. Yong Kim, In-vitro cytotoxicity and cell uptake study of gelatin-coated magnetic iron oxide nanoparticles, Journal of microencapsulation, vol. 28, pp. 240$247,2011$.

[18] H. Zamani, B. Rastegari, M. Varamini, Antioxidant and anti-cancer activity of Dunaliella salina extract and oral drug delivery potential via nano-based formulations of gum Arabic coated magnetite nanoparticles, Journal of Drug Delivery Science and Technology, vol. 54, pp. 101278,2019.

[19] M.S.C. Kumar, V. Selvam, M. Vadivel, Synthesis and characterization of silane modified iron (III) oxide nanoparticles reinforced chitosan nanocomposites, Engineering Science \& Advanced Technology, vol.2, pp. 1258-1263,2012.

[20] S. Sharma, A. Hasan, N. Kumar, L.M. Pandey, Removal of methylene blue dye from aqueous solution using immobilized Agrobacterium fabrum biomass along with iron oxide nanoparticles as biosorbent, Environmental Science and Pollution Research, vol.25, pp. 21605-21615,2018.

[21] S. Sharma, S. Tiwari, A. Hasan, V. Saxena, L.M. Pandey, Recent advances in conventional and contemporary methods for remediation of heavy metal-contaminated soils, 3 Biotech, vol.8, pp.1-18,2018.

[22] N. Besharati, N. Alizadeh, S. Shariati, Removal of cationic dye methylene blue (MB) from aqueous solution 
by Coffee and Peanut husk Modified with Magnetite Iron Oxide Nanoparticles, Journal of the Mexican Chemical Society, vol.62, pp.110-124,2018.

[23] N. Malhotra, J.-S. Lee, R.A.D. Liman, J.M.S. Ruallo, O.B. Villaflores, T.-R. Ger, C.-D. Hsiao, Potential toxicity of iron oxide magnetic nanoparticles: A review, Molecules, vol.25, p. 3159,2020.

[24] S. Thakur, P.P. Govender, M.A. Mamo, S. Tamulevicius, V.K. Thakur, Recent progress in gelatin hydrogel nanocomposites for water purification and beyond, Vacuum, vol. 146, pp. 396-408,2017.

[25] M. Arakha, S. Pal, D. Samantarrai, T.K. Panigrahi, B.C. Mallick, K. Pramanik, B. Mallick, S. Jha, Antimicrobial activity of iron oxide nanoparticle upon modulation of nanoparticle-bacteria interface, Scientific reports, vol.5, pp. 1-12,2015.

[26] Y. Abboud, T. Saffaj, A. Chagraoui, A. El Bouari, K. Brouzi, O. Tanane, B. Ihssane, Biosynthesis, characterization and antimicrobial activity of copper oxide nanoparticles (CoO NPs) produced using brown alga extract (Bifurcaria bifurcata), Applied Nanoscience, vol.4, pp. 571-576,2014.

[27] Q. Wang, M. Shen, T. Zhao, Y. Xu, J. Lin, Y. Duan, H. Gu, Low toxicity and long circulation time of polyampholyte-coated magnetic nanoparticles for blood pool contrast agents, Scientific Reports, vol. 5, pp. $1-8,2015$.

[28] R.O. Rodrigues, M. Bañobre-López, J. Gallo, P.B. Tavares, A.M. Silva, R. Lima, H.T. Gomes, Haemocompatibility of iron oxide nanoparticles synthesized for theranostic applications: A high-sensitivity microfluidic tool, Journal of Nanoparticle Research, vol.18, pp. 1-17,2016.

[29] M. Imran, S. Riaz, S.M.H. Shah, T. Batool, H.N. Khan, A.N. Sabri, S. Naseem, In-vitro hemolytic activity and free radical scavenging by sol-gel synthesized $\mathrm{Fe}_{3} \mathrm{O}_{4}$ stabilized $\mathrm{ZrO}_{2}$ nanoparticles, Arabian Journal of Chemistry, vol.13, pp. 7598-7608,2020.

[30] B. Macías-Martínez, D. Cortés-Hernández, A. Zugasti-Cruz, B. Cruz-Ortíz, E. Múzquiz-Ramos, Heating ability and hemolysis test of magnetite nanoparticles obtained by a simple co-precipitation method, Journal of applied research and technology, vol.14, pp. 239-244,2016.

[31] M.P. Vinardell, M. Mitjans, Antitumor activities of metal oxide nanoparticles, Nanomaterials, vol.5, pp.1004$1021,2015$.

[32] K. Kojima, S. Takahashi, S. Saito, Y. Endo, T. Nittami, T. Nozaki, R.C. Sobti, M. Watanabe, Combined effects of $\mathrm{Fe}_{3} \mathrm{O}_{4}$ nanoparticles and chemotherapeutic agents on prostate cancer cells in vitro, Applied Sciences, vol.8, p.134, 2018.

[33] P. Nagajyothi, M. Pandurangan, D.H. Kim, T. Sreekanth, J. Shim, Green synthesis of iron oxide nanoparticles and their catalytic and in vitro anticancer activities, Journal of Cluster Science, vol.28, pp.245-257, 2017.

[34] M. A Al-Kinani, A. Haider Sharafaldin Al-Musawi., Study the Effect of Laser Wavelength on Polymeric Metallic Nanocarrier Synthesis for Curcumin Delivery in Prostate Cancer Therapy: In Vitro Study, Journal of Applied Sciences and Nanotechnology, vol. 1pp.43-5, 2021.

[35] N.N. Hussein, M., Khadum., Evaluation of the Biosynthesized Silver Nanoparticles Effects on Biofilm Formation, Journal of Applied Sciences and Nanotechnology, vol. 1, pp.23-31,2021. 